\title{
Paragraph Writing: A Process Based Model
}

\section{Batuk Lal Tamang}

Paragraph writing generally refers to developing a single idea on a given topic. I think teaching writing a paragraph is not a difficult task at basic and secondary levels (6-10 grades), as the students in Nepali context consider it as such. The skill used to write a paragraph could also be helpful even when one delivers speech on any of a number of topics. Writing a paragraph can be a joyful task if it follows a process-based model. This lesson focuses on teaching writing the paragraph while preparing teachers (pre-service) in post-secondary and bachelor's level in the university to teach primarily at secondary level.

Proficiency Level: Intermediate

Age Group: Young/adults $(10+2$ and bachelor's level)

Class Time: $90-100$ minutes

\section{Objectives}

On the part of students, the activities aim: 1) to familiarise them with what a paragraph basically is in regard to the secondary-level curriculum, including a grid regarding paragraph writing,2) to enable them to frame some topic sentences for paragraphs on several topics, 3) to help them learn how to support the topic sentences with other details, and 4) to write conclusions for a paragraph and reflect on the entire lesson.

Resources: handouts and worksheets

\section{Procedure}

1) What is a paragraph? (10 minutes) Distribute a paragraph (Nepali food: see activity-3) and ask the students in pairs to discuss what a paragraph is and elicit their opinions. Each pair shares with the whole group. Teacher enhances discussion on how the (Nepali food) paragraph begins, develops further and concludes.

2. Secondary level curriculum (5 minutes) Provide the information on what the focus is regarding paragraph writing at the secondary level. It includes objectives, major contents, teaching strategies and assessment process.

In relation to English grid of SEE (secondary education examination), students are asked questions in two ways: - Guided writing: Students are provided clues to writing a paragraph, which carries 5 marks and is limited to 75 to 100 words. - Free writing: Students are assigned to write on a personal experience on a certain topic. No hints are provided; the paragraph 
carries 6 marks and is limited to 100 to 120 words.

3. Read and find three major parts of paragraph (10 minutes) Make students read the following paragraph (descriptive) and find three basic parts of the paragraph: topic sentence, supporting ideas and concluding sentence.

\section{Nepalese Food}

Although Nepal is a small country, it has a large variety in food. Most food we use contain high in carbohydrates and protein which are high calories giving. The common food is rice, lentil gravy called daal, and curry. Some people have dhindo and gundruk (fermented and dried vegetable). Pickle called achaar is another sharp tasty variety of food. Chapati is another famous variety in low land region of south which is known as the bread basket of the country. Meat like mutton, chicken and fish are special dish used with other dishes. Some meats are restricted in our country in particular community such as beef is prohibited in Hindu community and pork in Muslim community. These are the some examples of Nepalese foods which most people eat.Extracted from: (Tamang, 2017)

\section{Discussion}

Make a discussion on the following types of questions.

a) What is the title of the paragraph? b) Which is the topic sentence in the paragraph? Is it the summary of the paragraph? Is this sentence related to the given title?

c) How many sentences are there in between the first and last sentences? Do these sentences support the topic sentence? Do the sentences create a flow?

d) What about the last sentence? Does this sentence conclude the idea of the topic?

4. Writing a paragraph: generating ideas (35 minutes) Teacher prepares students to write on some topics, for example; Modern Girl, My School, The Dog and The Book.

\section{Topic sentence (10 minutes)}

Students are divided into four groups and are given the above-mentioned topics, one for each. Teacher tells them to work in their group to write a topic sentence for each title. Students present their topic sentences in the class. The teacher and other groups provide feedback.

\section{Possible topic sentences on the given titles:}

- Modern girl: Modern girls are aware of their career.

- My school: My school, Annapurna Secondary School, is a renowned school in Chitwan district.

- The dog: The dog is an obedient animal. 
- The book: A book is a major source of information and knowledge.

Discuss what a topic sentence is to the whole class.

\section{The topic sentence:}

- Topic sentence can also be called the thesis statement/sentence, central idea of the topic/paragraph, controlling idea of the paragraph, general statement of the title, pilot sentence, and key sentence.

- It is written in a single sentence.

- It is generally written at the beginning of the paragraph, but sometimes in the middle or at the end of the paragraph.

- This sentence draws the reader's attention.

It controls or limits the area of explanation.

\section{Supporting details (20 minutes)}

Ask them to write supporting sentences for the topic sentence they have already written. Let each group present their supporting details in the class and have discussion over each presentation. Discuss how the topic sentence is elaborated and supported by other details.

\section{Supporting details:}

- Supporting details are written after the topic sentence to justify it.
- To justify the topic sentence, information is provided through different ways such as evidences, illustrations, clarification, examples, reasons, specific data or facts, personal experience or past stories.

- It is an act of elaboration of the topic sentence

- To make the continuous flow of the ideas/sentences, use transition words, such as therefore, thus, hence, for example, and, for instance, to name, to illustrate, in other words, in particular, specifically, such as, at the same time, moreover, likewise, then, after, and so on.

- Maintaining coherence is an important part of writing supporting details.

\section{Concluding sentence(5 minutes)}

Teacher asks them to write a concluding sentence for what they have written. Students present their concluding sentences in the class and teacher provides feedback on them.

\section{Concluding sentence:}

- It is an ending sentence of the paragraph.

- It summarises the details.

- It is very close to the topic sentence in meaning. 


\section{Editing and revision (10 minutes)}

This is the stage when a rough draft of a paragraph is written by each group. Students in a group work to edit the first draft; this includes proof reading for spelling, punctuation and grammatical correctness. Likewise, the teacher asks them to revise their paragraph writing in terms of appropriate topic sentence, its supporting ideas and conclusion. Further, while making revisions, students improve the coherence of the paragraph, including the use of connectives and transition words.

\section{Gallery walk (15 minutes)}

Each group pastes the final version of the paragraph on the wall. The teacher asks them to move around and read the paragraphs of each group. They can make comments on the paragraphs. Later, the teacher generates discussion with reference to the title, the three major parts of the paragraph and coherence.

\section{5. $\quad$ Further practice (15 minutes)}

The teacher provides students some topics for short paragraphs such as;

- A quarrel you have witnessed

- Exams

- Importance of education and

- Mt. Everest.

In next phase, the teacher presents them with different types of paragraphs apart from descriptive. They are narrative, argumentative and reflective ones (see Appendix 1) and discusses them in the classroom.

\section{Reflection}

In this phase, students will work on how paragraph writing could be better facilitated at secondary and basic levels using a process-based approach. The teacher can ask the following questions: Why is paragraph writing important? What does a paragraph mean? How is it written? What are the opportunities for students following process-based model?

\section{Additional information}

The lesson is an outcome of my experience of teaching and training in Nepal. It has focused on a teaching plan to write a paragraph at the secondary level and the upper grades of basic level. It has combined practical ideas and a structured lesson, using the process-based model of paragraph writing, with some theoretical ideas in paragraph writing as well for the students of pre-service teacher education programs in the university and postsecondary level.

\section{Reference}

Tamang, B. L. (2002). English practice book: for class 10 and SEE (Revised ed.) (2017). Kathmandu: Pragyan Prakashan.

\section{Contributor}

Batuk Lal Tamang is the head teacher of Annapurna Secondary School, Chitwan. He was the former chair of NELTA Chitwan branch and a teacher training of English at ETC Bharatpur. Mr. Tamang has been associated with ELT from school to university level and teacher training for one and a half decade in Nepal. He has received a 
TEA (teaching excellent award) fellowship for the USA in 2017 spring.

\section{Appendix 1: Sample paragraphs (from Tamang, 2017)}

a. Try to remember the most important event in your life and write it down in a paragraph. (Narrative)

It happened when I used to study at grade six. I was quite shy. I did not use to speak in front of the crowd. I felt difficult to speak formally in public. My school often conducted extracurricular activities in which my friends used to win and receive award in front of other students in the presence of teachers. I was quite fond of it. One day I decided to take part in story reciting competition. Though I was timid to speak formally, I was good at writing. I wrote a nice story and submitted to my class teacher. The program began. I felt very nervous. When the teacher called my name, I nearly fainted. How I completed the job I couldn't remember all. But I received second prize. Since then I attended the program regularly. My first attempt made me courageous to do a good job.

b. Write a paragraph on 'Importance of the wild animals' in about 100 words. Use the clues given below: (Reflective)

Wild animals are vital part of ecosystem. A big portion of ecosystem is occupied with wild animals. Since mankind is a member of ecosystem, our life is directly connected to wildlife. Its absence on the earth causes bad influence to us. Killing its one species is like removing a brick from the wall which ultimately make the wall weak. To make the ecosystem strong, they must be saved from being disappeared. To save them we should preserve their living place, the forest. Killing them without caring must be checked. We must be aware that the wild animals are our co-lives.

c. Write a paragraph on 'Television is boon for human being' in about 100 words. Use the clues given below: (argumentative)

(Advantages of TV, example of some useful TV channels and programs)

Invention of television is a boon for human being. Now we can't even imagine the life without it. Now it has become an excellent source of information and knowledge. From the books we can get only visual information, but from the television we can get both audio and visual information which is more effective way of learning something. The Discovery and National Geography channels are the international educational channels that impart genuine knowledge and information. Other national and local channels broadcast useful and entertaining programs. The tele-serials and musical programs are the perfect entertaining programs that refresh our mind. Therefore, television is a source of information as well as a means for entertainment. 